\title{
ELT IN INDIA IN CONTEXT TO THE ENGINEERING STUDENTS
}

\section{Dr. Heera G Rajwani}

\begin{abstract}
$\underline{\text { Abstract }}$
Language is a tool of communication where as a good presentation is a trick of the personality. If both are combined then it creates a masterpiece. In this 21 century no one can be deprived of English language. English is taught in our country as L1, L2 or L3, and as a foreign language. Whatever the scenario was prevailing in the olden days now is totally changed and a teacher of English faces lot of challenges in India. This paper deals with the importance of teaching English to fulfill the growing demands of English. The lacunae of teaching English in India are discussed. The challenges before today's teachers in present day in ELT with context to the Engineering students are taken up in this study. Particularly the students of engineering are very much in need of a good communication skill. If they are not developing the skill then it is so difficult to exist. As someone has rightly said that the fittest can survive. The way in which students can put their learning into practice in day-to-day use to fulfill their practical demands through effective communication skills apart from gaining command over English language is highlighted. This paper also deals with various language games which are introduced in teaching to create interest of students in learning English language apart from conventional learning. This paper also throws light on the need of English language teaching for engineering students.
\end{abstract}

Key words: L1, L2, FL, SL lacunae 


\section{Introduction}

Today, English is a sign of people's professional growth for quality in life and education which cover the way to participate in national and international scope. Its colonial origins now forgotten or irrelevant, its initial role in independence India, modified to high education now felt to be insufficiently inclusive socially and linguistically. The current state of English stem from its overwhelming presence on the world stage and the reflection of this in the national arena. The use of electronic educational resources is one of the dominant trends in the development of modern education practice in universities and hence, is dire referred to second language learning. The pedagogical experience being gained currently brings out clearly the didactic potential of modern technology in the intensification of second language teaching. I short English has acquired the global language status as it is spoken as second language in many countries of the world. It is key to the storehouse of ever growing knowledge of scientific, technological, commercial, literary, medical fields etc. On account of this, it is made part of the Indian education system to keep pace with the knowledge explosion and contribute to it.

English is taught for two different purposes: English for General purpose (EGP) and English for specific Purpose (ESP). The former is taught for laying a basic foundation in English and the latter intends to develop proficiency in the specific area of study. EGP should be taught till intermediate level, and ESP should be introduced from undergraduate level. In contrast, English is taught for general purposes at all levels of education immaterial of the stage it is taught in India without any clear identification of specific objectives, teaching material and methodology of teaching and evaluation. In foreign countries, there are specific ESP course which emphasize on the development of professional skills as per the specialization chosen.

\section{Origin of ESP}

There is profuse information about the origin of ES, most prominently there are three reasons state by Hutchinson and waters in 1987.

To meet the demands of the new world;

The revolution in linguistics and

Finally, to lay focus on the needs of the learners

According to Hutchinson and waters, there are two historical periods responsible for the growth of importance of ESP; first, the end of second World War which brought considerable and unprecedented expansion in scientific, technical and economic activity at the international level, 
second the oil crises in western money and knowledge flowing into the oil-rich countries. The language of this knowledge became English.

\section{Definition of ESP}

According to Hutchinson and waters, ESP is an approach to language teaching in which all decisions related to content and method are based on the learner's reason for learning. Therefore, according to strevens, ESP is English language Teaching (ELT) designed to meet specific needs of the learners.ESP is also specified as the one studied for academic and vocational or professional purpose. Michael Byram state ESP is a learner centered and need based approach which emerged during 1060s. This branch has emerged to widen the focus on the development of communicative competence in specific disciplines like medicine, aviation, academics, accounting, engineering etc.

According to knight, Lomperis, Van Naerssen and Westerfield the language learners are categorized into two types.

1. Language learners who are in the process of developing expertise in their fields need English communication skills as tools in their training.

2. Language learners who are already experts in their fields need English communication skills as tools in their work.

Undergraduate students' level students come under first category; that are in the process of developing expertise which will enable them to succeed in their future internships and jobs. The employed people come under second category that needs some kind of coaching for carrying on their specific duties at professional level.

Here is a case of several students. What is the meaning of update? This was one of the multiple choice questions asked to thousands of engineering graduates across the country as part of an English test. Nearly $40 \%$ of the grads opted for the wrong answer of 'increase' while $32 \%$ chose the correct answer' renew'.

With Chennai being ranked lowest among metros to have engineering graduates with good spoken English skills in a recent study, engineering colleges in Tamil Nadu are introducing programmes to combat this issue as they believe that students are not exposed enough to situations which require them to communicate well in English. 
In this situation how can a student cope in the career? Similar is the case of many engineering college students. It is observed that in spite of teaching communication skill many students are not getting ready to communicate real life situations. They are lacking not only in communication competence but also in performance. The syllabus, methodology, teaching objectives should be crystal clear in the curriculum of the Engineering students. It has been observed that sometimes the curriculum is something else and the paper style says some different pattern or it's not on the bases of blue print. Sometimes the course is not apt to the level of the students. Actually their course should be functions and need based.

Since many years English is taught in India but still the engineering students are not getting the fluency.

"Students coming from remote areas are not able to even construct a simple sentence when they enter engineering," faculty members of Engineering College have observed. The college conducts English tests to understand their proficiency levels and accordingly bring in trainers to coach students in different batches. When it is a time for recruiters then recruiters ask for good communication skills. Engineering colleges in the city say many students don't develop language skills at school. They point out those students score marks through rote learning at school level which they replicate at college too.

While English is present as a part of the curriculum in the first year of engineering, then the faculty members have been observed that language learning doesn't take place in classrooms as English is treated as 'yet another subject by students across colleges. Whether it is English or Environment Science, it is approached in the wrong way instead of using it to a tool to equip them.

While language labs are present in engineering colleges, English teachers further state that the proficiency depends on how effectively the language is taught in the classrooms. Since engineering sessions are full of technical jargons, it is not a way for students to learn effective communication. Teachers believe that colleges must create situations which require students to participate in presentations or interviews. Various colleges have started making the colleges well equipped with the latest software to teach language skills and some have started online teaching but it has been clearly visible that very few excel in it. 
Teachers in colleges say it is a bigger challenge in non-urban areas where it becomes a greater responsibility for institutions to ensure that students are trained better. As per a study released by Aspiring Minds, an employability assessment company, students in non-metros scored lower than those in metros in all parameters of fluency, pronunciation, spoken English, vocabulary, grammar, voice modulation and active listening. According to a study conducted by a teacher among 1,500 non-English medium students who entered engineering courses, found that more than 50\% did not read English material other than their textbook nor have watched English TV channels.

Poor spoken English may be keeping a large number of India's engineers from landing some of the best paid jobs in the country. A study has found that an overwhelming 97 per cent of engineers in the country cannot speak English, required for high-end jobs in corporate sales and business consulting. Moreover, as per the report based on the study, about 67 per cent of engineers graduating from India's colleges do not possess spoken English skills required for any job in knowledge economy.

The study, 'The National Spoken English Skills of Engineers Report', conducted by Aspiring Minds, surveyed English skills study of 30,000 engineers across 500 engineering college.

Although the problem is far more pronounced in tier 2 and tier 3 colleges, instilling spoken English skills is a big challenge in Indian Institutes of Technology and National Institutes of Technology as well. About 600,000 engineers graduate annually in India.

The key problem faced by engineers is pronunciation, followed by fluency skills, grammar and sentence construction. Engineers show a larger gap in elements of spoken English, pronunciation and fluency, followed by grammar, though they do relatively better in vocabulary and understanding English.

As per the report, only 6.8 per cent engineers show the ability to speak or respond spontaneously. This leads towards the learning to English Language. This can be improved by the efforts of the teachers of English. The class interaction and lot of efforts put by the students. This leads to the language activities done in the class. 


\section{Language Activities}

Here are some of the activities which can help a teacher to meet the challenges of teaching English.

\section{Role Plays}

Role-plays are another important task that can improve the basic colloquial English of the learners. In role plays, the students assume themselves as one of the characters and behave and speak accordingly involving in the given character completely. In these types of activities teachers have to play a vital role as instructors and guide the students properly so that they can act appropriately to meet the situation. They should help the students now and then to understand and take up the role given to get a grip on the tone of voice.

\section{Debates}

Debates too play an important role to improve the speaking ability of the students both at school and at higher level. Debates not only make the students to speak boldly and fluently but also help them to take one stand and be firm and consistent on that. Along with this advantage of reasoning, it gives students some experience to control their emotions without losing their temper. This also helps them to organize their thoughts and ideas in a specific way while speaking.

\section{Group Discussions}

Now due to the world wide growing trends in English, teachers give more emphasis to communicative approach rather than the lecture mode. Their main goal is to make the students effective communicators in English both inside and outside the class room.To achieve this, they involve the students to participate more in classroom activities so that they will acquire adequate command over speaking skills.

To create this environment, teachers can conduct group discussions, where students are supposed to speak only in English. Here, they can give their views, ideas and thoughts in 
English due to which they develop the habit of speaking fluently in English like they do in their mother tongue. Various types of discussions also help students to improve their general awareness and understanding about current affairs. It gives a lot of scope for good imagination and deep thoughts. This type of discussions helps the students to listen to the views of fellow students which in turn helps them to gain knowledge and enrich the vocabulary also.

\section{Conclusion}

Even there are enormous challenges before the English language teachers in India .The teacher should be able to cater to the practical needs of learners, to make them competent enough to interact with one another and also to retrieve information all over the world. To meet the present day challenges in teaching English, first of all, English should not be treated as a subject as it is to be used actively in interacting with one another throughout the world. By using conventional methods, maximum portion of class time will be spent in exercises and drilling, dealing with grammar and pronunciation which takes away a large portion of class time. English has a base in several countries and is considered as the most suitable and convenient tool for International Communication. The people who have proficiency in this language could access large number of jobs and also were seen holding high positions in many National and International Organizations.

In the earlier days English was just like a Library language, but now that notion has changed totally. At present the challenges visible before the English language teachers in India are diverse and it is necessary for them to shape up accordingly to meet the demands of the day. 
Towards Excellence: An Indexed, Refereed \& Peer Reviewed Journal of Higher Education / Dr. Heera Rajwani / Page 93-100

\section{$\underline{\text { References: }}$}

L .N. Kinnock.2006. The "English factors in globalization", Those Who Wish To Influence The Future Must Prepare For It. Page 7

Jacob Tharu, 2006. "A second look at English as a window on the world that has changed," Communication Curriculum in Higher Communication: Challenges \& Opportunities

The Journal of English Language Teaching (India) vol.59/1 January-February 2017 ISSN No 0973-5208

The Journal of English Language Teaching (India) Vol.58/5 September-October 2016 ISSN No 0973-5208

The Journal of English Language Teaching (India) Vol.58/6 November- December 2016 ISSN No 0973-5208

www.lapasserelle.com/1m/excercises/games.page.html

http://economictimes.indiatimes.com/industry/jobs/how-english-speaking-skills-are-keepingindian-engineers-away-from-their-dream-jobs/articleshow/48384078.cms?intenttarget=no

http://timesofindia.indiatimes.com/home/education/news/Engineering-colleges-to-teachstudents-better-English/articleshow/48548932.cms

\section{Dr. Heera G Rajwani}

Head of the Department

Dept. of English and Communication Skills

Humanities and Science Department

Noble Group of Institutions

Junagadh 